\title{
'REVENGE PORN': A VICTIM FOCUSED RESPONSE
}

\author{
ALYSE DicKSON*
}

This article argues that the Australian Parliament should provide victims of revenge pornography with a victim focused response to enable the fast removal of intimate images from the internet and to mitigate the harm that the ongoing public access to the images can cause. Part I outlines the reasons why revenge pornography has created a new problem for the law. Part II addresses the existing legal remedies and Part III outlines the different approaches that the Australian Parliament could plausibly adopt. It argues that while criminal laws and civil remedies may assist, they do not provide efficient remedies for victims. The article concludes that the Australian Parliament should extend the powers of the Children's e-Safety Commissioner to deal with adult victims as well as child victims and thereby facilitate the fast removal of revenge pornography from the internet.

\section{NOTE FROM THE EDITORS}

This article was accepted for publication in September 2016. On 23 November 2016, the Commonwealth Government announced that online safety expert Julie Inman Grant would take on a newly-expanded role of e-Safety Commissioner, aimed at combating the non-consensual sharing of intimate images, commonly referred to as 'revenge porn'. The editors decided to publish the article in its original form, but extra information and footnote references have been added where possible.

\section{CONTENTS}

Revenge Pornography. 44

II Existing Legal Remedies 47

A Criminal Law...........................................................4 47

1 Problems with Enforcement ................................................ 50

2 Not a Victim Focused Response......................................... 51

* LLB student, School of Law, University of South Australia. 


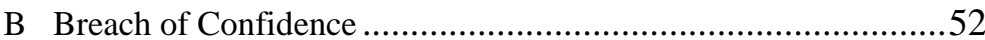

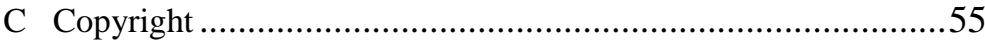

III Alternative Approaches ............................................................. 56

A Action for Serious Invasion of Privacy..........................56

B The Australian Online Safety Response for Children...........59

C The New Zealand Response .........................................62

1 Criminal Offence .............................................................. 63

2 Civil Enforcement Regime ............................................ 64

3 Safe Harbour Provisions ...................................................... 66

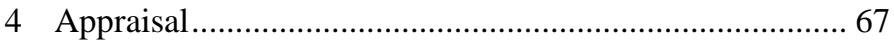

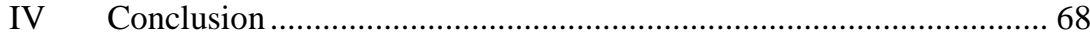

\section{INTRODUCTION}

The phenomenon known as 'revenge porn' was brought into the national spotlight in 2015, when intimate photographs and videos of over four hundred South Australian women were uploaded and made available for viewing on a United States revenge pornography website without their permission. ${ }^{1}$ Advances in communication and information technology mean that taking and distributing intimate images is easier and more accessible than ever. Recent statistics reveal that one in ten Australian adults has had an intimate image sent to others without their permission. ${ }^{2}$ This behaviour can cause severe psychological injury ${ }^{3}$ for victims who feel they no longer have control over who can see that intimate image. In response to the phenomenon, Australian

Australian Broadcasting Corporation, 'Hundreds of Australian Women Falling Victims of 'Revenge Porn' Websites Raises Legal Questions', 7:30 Report, 18 June 2015 (Alex Mann) <http://www.abc.net.au/7.30/content/2015/s4257906.htm>.

2 Anastasia Powell and Nicola Henry, 'Digital Harassment and Abuse of Adult Australians: A Summary Report' (2015), $2<$ https://research.techandme.com.au/wpcontent/uploads/REPORT_AustraliansExperiencesofDigitalHarassmentandAbuse.pdf>.

3 Senate Legal and Constitutional Affairs References Committee, Parliament of Australia, Phenomenon Colloquially Referred to as 'Revenge Porn', which Involves Sharing Private Sexual Images and Recordings of a Person without their Consent, with the Intention to Cause that Person Harm, (2016) 20. 
law reform committees have focused inquiries on the adequacy of existing civil remedies and the need to enact specific criminal offences. ${ }^{4}$

These law reform groups have not taken the further step of considering how best to respond to a victim's need for speedy action to remove the images from the internet as quickly as possible. ${ }^{5}$ This article argues that the Australian Parliament needs to provide a response that restores a sense of control to victims. This is a response that enables the fast removal of intimate images and mitigates the harm that the ongoing public access to the images can cause. Part I explains why revenge pornography has created a new problem for the law. Part II addresses the existing legal remedies and the problems associated with those remedies in the context of revenge pornography. Part III then outlines alternative approaches that the Federal Parliament could plausibly adopt. This part then argues that the Federal Parliament should implement a specific government agency to deal with complaints from revenge pornography victims and to facilitate the fast removal of the material from the internet.

\section{REVENGE PORNOGRAPHY}

The internet is becoming part of everyday life, with over 86 per cent of households having access to the internet. ${ }^{6}$ It can be accessed through an array of devices such as desktop and laptop computers, mobile or smart phones, tablets, smart televisions, game consoles and portable media players. In 2015, it was reported that 93 per cent of Australian adults use mobile phones, ${ }^{7}$ and

4 Australian Law Reform Commission, Serious Invasion of Privacy in the Digital Era, Final Report (2014) 9-14; see also recommendations 2 and 6, Senate Legal and Constitutional Affairs References Committee, above n 3, vii-viii.

5 Since the time of writing, the Commonwealth Government has now moved to introduce a package of reforms aimed at combatting the non-consensual sharing of intimate images by developing a new online reporting tool and announcing a public consultation process to discuss a proposed civil penalties regime targeted at both perpetrators and sites which host intimate images and videos shared without consent. See Minister for Communications and Minister for Women, 'New eSafety Commissioner Appointed in Expanded Role to Combat Non-Consensual Sharing of Intimate Images’ (Media Release, 23 November 2016).

6 Australian Bureau of Statistics, Household Use of Information Technology, Australia, 201415, cat no 8146.0 (17 February 2016)

<http://www.abs.gov.au/ausstats/abs@.nsf/0/ACC2D18CC958BC7BCA2568A9001393AE? Opendocument>.

7 Australian Communications and Media Authority, Communications Report 2014-15 (2015), 21

<http://www.acma.gov.au/ /media/Research\%20and\%20Analysis/Report/pdf/ACMA\%20C ommunications\%20report\%202014-15\%20pdf.pdf $>$. 
nearly 80 per cent use their mobile phones to access the internet. ${ }^{8}$ Ease of access allows people to be connected to the internet anywhere and at any time. Most smart phones come equipped with inbuilt photographic and recording capabilities, making it easier to take and store images. In the past, distributing an intimate image required physical effort and considerable time. It involved physically developing films, photocopying, sending by post or distributing by hand to the public. Today, intimate images can be distributed easily and instantaneously by text messages, email or by uploading the images to social media, blogs or dedicated revenge pornography websites. The global nature of the internet means that there are potentially billions of people who can access, view and redistribute images made available online. These advances have given rise to the 'revenge porn phenomenon.'

'Revenge porn' is a media generated term used to describe the non-consensual distribution of intimate photographs or videos of another person, with the intention of causing them harm. ${ }^{9}$ It is also known as 'image-based sexual exploitation' or 'image-based sexual abuse'. ${ }^{10}$ The intimate image may have been originally obtained with or without the consent of a victim. Images taken without consent include images illegally obtained through hidden camera devices ${ }^{11}$ and images stolen from a person's online storage, computer or other device. More recently, new varieties of image-based sexual abuse known as 'parasite porn' and 'morph porn' have emerged. ${ }^{12}$ In these examples, harmless social photographs of victims are stolen, copied and uploaded onto pornography sites ('parasite porn'); or a victim's face is copied, cropped and

$8 \quad$ Ibid 46.

9 Senate Legal and Constitutional Affairs References Committee, above n 3, 2.

10 Explanatory Memorandum, Criminal Code Amendment (Private Sexual Material) Bill 2015 (Cth) 2 [2] uses 'image-based sexual exploitation'. See also: Clare McGlynn and Erika Rackley, 'Not 'Revenge Porn", but Abuse: Let's Call it Image-based Sexual Abuse' on Inherently Human, Inherently Human (online), 15 February 2016, $\leq$ https://inherentlyhuman.wordpress.com/2016/02/15/not-revenge-porn-but-abuse-lets-callit-image-based-sexual-abuse/>; Nicola Henry, 'Henry Responds to Dickson: "Revenge Porn": A Victim Focused Response’ (2016) 2 University of South Australia Student Law Review 70.

11 Summary Offences Act 1953 (SA) s 26D(1) makes it an offence 'engage in indecent filming' and s $26 \mathrm{D}(3)$ makes it an offence for a person to 'distribute an image obtained by indecent filming'.

12 Jake Sturmer and Alison Branley, 'Noelle Martin Fights to Have Harmless Selfie Removed from "Parasite" Porn Sites' ABC News (Online) <http://www.abc.net.au/news/2016-1012/womans-fight-to-have-harmless-selfie-removed-from-porn-site/7924948>. 
pasted onto the body of another person who is engaging in explicit sexual acts ('morph porn'). ${ }^{13}$

The term 'revenge porn' is misleading because revenge is not always the motive for non-consensual sharing of an intimate image of another. Typically, the distribution of the intimate image will be by a current or former partner as a form of domestic abuse. ${ }^{14}$ Partners may threaten to publish an intimate image in an attempt to prevent their partner from leaving the relationship or as revenge following the breakdown of the relationship. ${ }^{15}$ The distribution of the image is usually intended to shame, humiliate, punish or harass those who are depicted in the images. ${ }^{16}$ Strangers or acquaintances can also distribute these images for entertainment, notoriety and sexual gratification. ${ }^{17}$ Furthermore, there are specific 'revenge porn' websites dedicated to earning money from the sharing of non-consensual intimate images. Australian parliaments must ensure that legal responses are broad enough to capture the range of conduct and the variety of motives that influence this conduct, to ensure that victims of revenge pornography are adequately protected.

The harm to victims caused by distributing a non-consensual intimate image also varies depending on the circumstances. Revenge pornography websites commonly include victims' personal information such as full names, where they live, email addresses and phone numbers. When personal details are disclosed, victims may experience online or face-to-face harassment, stalking and threats to their safety. ${ }^{18}$ The distribution of an intimate image can cause shame and humiliation to the victims as well as their partners and family

13 Ibid. See also Senate Legal and Constitutional Affairs References Committee, above n 3, 24.

14 Nicola Henry and Anastasia Powell, 'Beyond the "Sext": Technology-Facilitated Sexual Violence and Harassment Against Adult Women' (2014) 48(1) Australia and New Zealand Journal of Criminology 104, 113; Charissa Sun, 'Technology-Facilitated Stalking and Abuse: Putting Our Legal Framework to the Test' (2015) 12 Law Society of New South Wales Journal 78,78 .

15 Danielle Citron and Mary Franks, 'Criminalizing Revenge Porn' (2014) 49 Wake Forrest Law Review 345, 349 .

16 Ibid 351

17 Senate Legal and Constitutional Affairs References Committee, above n 3, 19.

18 Nicola Henry, Asher Flynn and Anastasia Powell, Submission to Senate Legal and Constitutional Affairs Committee, Inquiry into the Phenomenon Colloquially Referred to as 'Revenge Porn', which Involves Sharing Private Sexual Images and Recordings of a Person Without Their Consent, with the Intention to Cause that Person Harm, 13 January 2016, 3. See also Sturmer and Branley, above n 12. 
members. It can damage relationships, reputations and career prospects. ${ }^{19}$ Victims who have taken the image themselves or who have consented to the taking of the image are often blamed for engaging in the conduct. ${ }^{20}$ Once the images have been distributed, they are, for the most part, irretrievable. Even if the original intimate image is removed, it is almost impossible to ensure it is gone forever. ${ }^{21}$ Victims may constantly live in fear that family, friends, lovers or employers will discover the images. This can cause severe emotional distress such as anxiety and depression. The severity of that emotional distress may be so overwhelming that it can cause some victims to commit suicide.

The ease with which intimate images can now be disseminated on the internet and the serious harm that these images can cause to victims has put increasing pressure on Australian parliaments to consider, and implement, appropriate means of legal protection. Given the effect that revenge pornography can have on victims, the reduction of harm in conjunction with, or in addition to, deterring perpetrators with criminal sanctions and compensating victims with civil remedies should be a priority. What follows is an appraisal of the existing legal remedies, which questions whether those remedies provide victims with a means of restoring dignity and reducing the harm that revenge pornography can cause.

\section{EXISTING Legal REMEDIES}

\section{A Criminal Law}

In response to the harm that non-consensual distribution of intimate images can cause, the South Australian and Victorian Parliaments have enacted specific revenge pornography offences. In South Australia it is an offence to distribute an invasive image of a person, knowing or having reason to believe that the other person does not consent to the distribution. ${ }^{22}$ An invasive image is defined as a 'moving or still image of a person engaged in a private act or in a state of undress' where the genitals or anal region are visible. ${ }^{23}$ The South Australian Parliament recently passed the Summary Offences (Filming and

19 Senate Legal and Constitutional Affairs References Committee, above n 3, 20.

20 Henry, Flynn and Powell, above n 18, 3.

21 Scott Stroud, 'The Dark Side of the Online Self: A Pragmatist Critique of the Growing Plague of Revenge Porn' (2014) 29 Journal of Mass Media and Ethics 168, 171.

22 Summary Offences Act 1953 (SA) s 26C as amended by Summary Offences (Filming Offences) Amendment Act 2013 (SA) s 5.

23 Summary Offences Act 1953 (SA) s 26A (interpretation of 'invasive image'). 
Sexting Offences) Amendment Act 2016, which extended the law to criminalise threats to distribute an invasive image of a person with the intent to arouse fear that the threat will be, or is likely to be, carried out. ${ }^{24}$

In Victoria, it is an offence for a person to intentionally distribute, or threaten to distribute intimate images without consent 'where the distribution of the image is contrary to community standards of acceptable conduct. ${ }^{25}$ While similar to an invasive image, an intimate image includes 'a person engaged in a sexual activity', 'in a manner or context that is sexual' or which depicts the genitals, anal region and in the case of females, the breasts. ${ }^{26}$ While other jurisdictions are yet to follow suit, existing offences have been used to secure convictions for this wrong. In New South Wales the offence of publishing an indecent article was used to convict a jilted ex-boyfriend in Police $v$ Ravshan Usmanov. ${ }^{27}$ In that case, Usmanov was sentenced to six months in jail for posting six nude photographs of his ex-girlfriend on his Facebook page. ${ }^{28}$ Beyond the laws that specifically target the non-consensual distribution of intimate films or images, other laws forbidding stalking, ${ }^{29}$ blackmail, ${ }^{30}$

24 Summary Offences Act 1953 (SA) s 26D as amended by Summary Offences (Filming and Sexting Offences) Amendment Act 2016 (SA) s 26DA. See David Plater, "Setting the Boundaries of Acceptable Behaviour"? South Australia's Latest Legislative Response to Revenge Pornography' (2016) 2 University of South Australia Student Law Review 77.

25 Summary Offences Act 1966 (Vic) ss 41DA, 41DB as amended by Crimes Amendment (Sexual Offences and Other Matters) Act 2014 (Vic) s 25.

26 Summary Offences Act 1966 (Vic) s 40 (definition of 'intimate image').

27 [2011] NSWLC 40.

28 Ibid. On appeal, the Local Court ordered that Mr Usmanov serve the sentence of imprisonment by way of home detention. A further appeal to the District Court confirmed the sentence of imprisonment but quashed the Home Detention Order and made an order for suspended sentence: Usmanov v R [2012] NSWDC 290 (15 February 2012) [5]-[6].

29 In Queensland, it is an offence under s 359B(c)(vi) of the Criminal Code 1899 (Qld) to, on more than one occasion, engage in 'an intimidating, harassing or threatening act against a person, whether or not involving violence or threat of violence'.

30 In Tasmania, s 241 of the Criminal Code 1924 (Tas) makes it an offence for a person to make an unwarranted demand with menaces, 'with a view to temporary or permanent gain for himself or for any other person or with intent to cause temporary or permanent loss to any other person'. 
voyeurism ${ }^{31}$ and indecency, ${ }^{32}$ may also offer some protection to victims of revenge pornography.

At Commonwealth level, the offence of misusing a carriage service may be used to secure a conviction for revenge pornography. ${ }^{33} \mathrm{~A}$ person misuses a carriage service if they do so in a way that reasonable persons would regard as being menacing, harassing or offensive. ${ }^{34}$ When deciding whether a reasonable person would regard particular material as offensive, the 'standards of morality, decency and propriety generally accepted by reasonable adults' is taken into account. ${ }^{35}$ This offence does not, however, address the consent of the victim and may not apply where there has not been a continuing course of conduct. ${ }^{36}$ To improve protection for victims, the Commonwealth Parliament is currently considering the Criminal Code Amendment (Private Sexual Material) Bill 2015 (Cth) ('the Private Sexual Material Bill') that will make revenge pornography a specific offence..$^{37}$

The Private Sexual Material Bill makes it an offence for a person to use, or threaten to use, a carriage service to transmit, make available, publish or distribute private sexual material without consent and with the intention, or risk, of causing that person harm or distress. ${ }^{38}$ A person who commits an offence may face up to five years imprisonment. The Private Sexual Material Bill also targets revenge pornography websites, by making it an offence to have control of private sexual material and supply that material for the purpose of obtaining a benefit. ${ }^{39}$ This is regarded as an aggravated offence and can attract a higher penalty. Private sexual material covers material that depicts a person who is 'engaged in, or appears to be engaged in, a sexual pose or

31 In New South Wales, s 91J of the Crimes Act 1900 (NSW) makes it an offence for a person who, 'for the purpose of obtaining sexual arousal or sexual gratification, observes a person who is engaged in a private act: (a) without the consent of the person being observed, and (b) knowing that the person being observed does not consent'.

32 In Western Australia, 'a person who unlawfully and indecently assaults another person is guilty of a crime': s 323 Criminal Code 1913 (WA).

33 Criminal Code Act 1995 (Cth) s 474.17.

34 Ibid.

35 Ibid s 473.4

36 Jonathan Clough, “"Revenge Porn” Criminal Law Responses' (2016) 132 Precedent 30, 31.

37 Criminal Code Amendment (Private Sexual Material) Bill 2015 (Cth).

38 Ibid ss $474.24 \mathrm{E}, 474.24 \mathrm{~F}$

39 Ibid s 474.24G. 
activity. ${ }^{40}$ It also covers material that depicts the sexual organ or anal region of a person and the breasts of a female or a person who identifies as female. ${ }^{41}$

On the one hand, the penalties that the Private Sexual Material Bill imposes on offenders sends a strong message that this conduct will not be tolerated and may also act as an adequate deterrent. On the other hand, requiring a victim to demonstrate that they have suffered distress and harm not only fails to put the needs of victims at the forefront but may also result in re-victimisation. The Private Sexual Material Bill does not provide a mechanism to enable victims to quickly remove the images from the internet. The Private Sexual Material Bill is appropriate to ensure offenders can be convicted. However, it does not provide victims with a means of restoring control over the images or of mitigating the harm that ongoing public access to the images can cause. ${ }^{42}$

\section{Problems with Enforcement}

Many leading articles addressing revenge pornography discuss the need for remaining jurisdictions to legislate specific and uniform revenge pornography offences. ${ }^{43}$ This is because the lack of specific offences and uniformity between jurisdictions has resulted in a number of problems for law enforcement and prosecution agencies. The South Australian and Victorian statutes lack uniformity both as to the definition of the prohibited material and the intent to cause harm. This lack of uniformity, coupled with the lack of specific laws in other jurisdictions, can result in victims falling through gaps in the law depending on where they live or where the perpetrator is located. ${ }^{44}$ In jurisdictions where no specific offence exists, law enforcement and prosecution agencies are often left unable to pursue complaints and secure convictions for revenge pornography at all. ${ }^{45}$ As Nicola Henry, Asher Flynn and Anastasia Powell ${ }^{46}$ argue, existing offences are too broad to capture the different forms of conduct, motives and harm that revenge pornography

\footnotetext{
40 Ibid s 474.24D(a)(i).

41 Ibid ss $474.24 \mathrm{D}$ (a)(iii)-(iv).

42 This Bill lapsed at prorogation on 15 April 2016.

43 See, eg, Clough, above n 36; Carianne Blyth and Lynne Roberts, 'Public Attitudes towards Penalties for Sexting by Minors' (2014) 26(2) Current Issues in Criminal Justice 143; Anastasia Powell and Nicola Henry, 'Blurred Lines? Responding to "Sexting" and GenderBased Violence among Young People’ (2014) 39(2) Children Australia 119.

44 Powell and Henry, above n 2, 4

45 Senate Legal and Constitutional Affairs References Committee, above n 3, 22.

46 Henry, Powell and Flynn, above n 18.
} 
encompasses. ${ }^{47}$ For example, stalking offences often require the perpetrator to engage in repeated acts which are directed at the victim. This means that any single posting of an intimate image onto an internet site and any sending of images to third parties may not be captured. This can leave victims of revenge pornography without access to justice. ${ }^{48}$

Another challenge for law enforcement and prosecution agencies is that the identity of the perpetrator may not be known, if for example, the offence occurs in other countries. In these cases it will be particularly difficult for law enforcement to obtain evidentiary material, and moreover, the perpetrator will not be subject to Australian laws unless a territorial nexus exists. ${ }^{49}$ Individuals who engage in revenge pornography will often do so in a way that preserves their anonymity. Website hosts may not be willing to disclose the identity of a person who publishes the material and at present, there are no legal sanctions for website hosts who refuse. Addressing these challenges can be time consuming for law enforcement agencies and in the meantime intimate images remain circulating on the internet. The establishment of a specific government agency to deal with complaints of revenge pornography and to facilitate the fast removal of images would not only mitigate the potential harm caused by lengthy delays; it would also remove this burden from law enforcement and prosecution agencies who could then focus their resources on obtaining evidence and securing convictions.

\section{Not a Victim Focused Response}

Criminal investigations can often be a traumatic experience for victims. Victims will usually be forced to share the images with police officers, lawyers, judges and court attendees. Criminal proceedings are also public and many victims may not want this kind of publicity. Consequently, this public process can lead to further shame and humiliation. Where a criminal conviction is secured, state and federal police have the power to remove the images from the website or social media platform where they were originally shared. ${ }^{50}$ However, by the time a conviction has occurred, the harm to the victim could well have amplified. The criminal law plays an important role in setting boundaries of appropriate conduct in society, protecting the safety of the

\footnotetext{
7 Ibid 3.

48 Henry, Powell and Flynn, above n 18, 4.

49 Criminal Law Consolidation Act 1935 (SA) s 5G.

50 Telecommunications Act 1997 (Cth) s 313.
} 
community and imposing sanctions on those who commit crimes. ${ }^{51}$ Criminalising revenge pornography sends an important message to the public that the conduct is not acceptable and punishment may also deter other perpetrators. Victims may find some vindication once offenders have been convicted and punished, but apart from providing an entitlement to victims' compensation, ${ }^{52}$ the criminal law does not provide victims with an efficient and accessible means for obtaining the removal of revenge pornography from the internet. While criminal laws are important, they are not sufficient in isolation. ${ }^{53}$

\section{B Breach of Confidence}

Breach of confidence has been used on two occasions in Australia to compensate victims of revenge pornography. Breach of confidence is an equitable remedy that can be used to protect personal information. ${ }^{54}$ To establish an action for breach of confidence in Australia, the following elements must be satisfied:

a) the information is confidential;

b) the information was imparted in circumstances importing an obligation of confidence; and

c) there has been an unauthorised use or threatened use of the information. ${ }^{55}$

In a claim for breach of confidence, plaintiffs will usually seek one or more remedies, including: an injunction to restrain an anticipated or continuing breach; an account of the profits derived from the breach; or compensation for the economic loss due to the breach. ${ }^{56}$

In Giller v Procopets ('Giller'), ${ }^{57}$ the plaintiff, Ms Giller, and the defendant, $\mathrm{Mr}$ Procopets, had created a videotape during their relationship showing them participating in sexual activities. After the relationship broke down, the

51 See, eg, Criminal Law (Sentencing) Act 1988 (SA) s 10(2)(a).

52 See, eg, Victims of Crime Act 2001 (SA) pt 5.

53 Clough, above n $36,33$.

54 Margaret, Duchess of Argyll v Duke of Argyll [1967] Ch 302.

55 Commonwealth of Australia v John Fairfax \& Sons (1980) 147 CLR 39 [51] (Mason J).

56 Australian Medic-Care Co Ltd v Hamilton Pharmaceutical Pty Ltd (2009) 261 ALR 501 [674].

57 (2008) 24 VR 1. 
defendant disclosed the videotape to the plaintiff's friends and family, ${ }^{58}$ causing Giller deep humiliation. The Victorian Supreme Court of Appeal awarded the plaintiff damages for the emotional distress caused by the defendant's breach of confidence in distributing a film that she had trusted him to keep private. ${ }^{59}$ This was a landmark decision in Australia. It was the first time that an Australian appellate court had accepted the invitation made by Gummow and Hayne JJ in Australian Broadcasting Corporation v Leah Game Meats Pty ${ }^{60}$ to develop an existing cause of action ${ }^{61}$ to protect privacy interests. ${ }^{62}$ Furthermore, this was the first time that equitable damages were awarded for emotional distress falling short of psychiatric injury for breach of confidence. ${ }^{63}$

Eight years later, Giller was followed by the Western Australian Supreme Court in Wilson v Ferguson ('Wilson') ${ }^{64}$. In that case, the plaintiff and the defendant had sent sexually explicit photographs and videos to each other during their relationship. The plaintiff had also recorded sexually explicit videos of herself, which the defendant stole from her phone. After the relationship had ended, the defendant uploaded those photos and images to his Facebook page. ${ }^{65}$ The Court awarded the plaintiff equitable compensation for the emotional harm that she suffered. There are, however, potential difficulties for victims of revenge pornography who attempt to rely on an action in breach of confidence to remedy the harm.

Breach of confidence may not be broad enough to capture all types of revenge pornography and the time it takes to seek a remedy may cause victims further emotional distress. In Giller and Wilson an expectation of privacy arose because the images had been created while the parties were in sexual relationships. In circumstances where images are stolen from a person's social media page or an online storage device by a stranger, an obligation of confidence may not necessarily arise. In those situations, the victim may be

58 Ibid [124]-[125].

59 Ibid [223].

60 (2001) 208 CLR 199.

${ }^{61}$ Australian Broadcasting Corporation v Leah Game Meats Pty (2001) 208 CLR 199, 250 (Gummow and Hayne JJ).

62 Ibid 225.

63 Ibid 431

64 [2015] WASC 15.

65 Wilson v Ferguson [2015] WASC 15 [17]-[42]. 
left without a civil remedy. The time and cost that an action in breach of confidence can take may also deter victims from using this action to seek justice. The 12 year $^{66}$ battle for justice in Giller was costly and left Ms Giller wondering whether it had all been worthwhile. In a magazine interview given in $2009,{ }^{67}$ Ms Giller said that if she had known that it would take so long she 'probably wouldn't have proceeded with the case' and would 'ditch the cash in an instant if it meant that no one had seen the video.' ${ }^{68}$ Accordingly, leaving victims to rely on an action in breach of confidence is not a response that captures the wide range of conduct that revenge pornography consists of and is not a response that focuses on the reduction of harm.

The availability of equitable compensation for emotional harm caused by revenge pornography has also been criticised ${ }^{69}$ The jurisdiction of equity to award compensation for emotional distress has never been considered by the High Court of Australia. ${ }^{70}$ At common law, damages will not usually be awarded for mental harm that falls short of psychiatric injury. ${ }^{71}$ The decision to allow equitable compensation for mental distress in Giller was based on there being no remedy for Ms Giller at common law. As Geoffrey Hancy ${ }^{72}$ has explained, equitable compensation is a proprietary remedy that developed in the context of breach of trust and fiduciaries. ${ }^{73}$ The remedy is usually concerned with proprietary and economic interests and not personal harm. ${ }^{74}$ Furthermore, Meagher, Gummow and Lehane argue that the English authority relied upon in support of awarding equitable compensation for mental distress in Giller did not support the conclusion that their Honours reached. ${ }^{75}$

66 The defendant showed videotape to another person in 1996, proceedings were initiated in 1999 and the Court of Appeal's decision was handed down December in 2008: Giller v Procopets (2008) 24 VR 1, [368], [56].

67 Katherine Chatfield, 'Revenge Porn: The On-line Trend You Need to Know About', Madison Magazine, Australia, April 2009, 52.

68 Ibid 56.

69 Geoffrey Hancy, 'The Law of Equity, the Information Age and Revenge Porn' (2015) 42(6) Brief 20; John Dyson Heydon, Mark James Leeming and Peter G Turner, Meagher, Gummow and Lehane's Equity: Doctrines and Remedies (2014, $5^{\text {th }}$ ed, Butterworths) 881-884.

70 Giller v Propocets (2008) 24 VR 1, 29 [133] (Ashley JA).

71 Ibid 32 [148] (Ashley JA), [426]-[427] (Neave JA).

72 Hancy, above n 69.

73 Ibid, citing Giller v Propocets (2008) 24 VR 1, [146] (Ashley JA).

74 Hancy, above n 69, 22 citing Heydon, Leeming and Turner, above n 69, 865 [23.605].

75 Heydon, Leeming and Turner, above n 69, 881. 
Accordingly, if another case ever reaches the High Court of Australia, there is a possibility that the approach taken in Giller and Wilson could be overturned. ${ }^{76}$ Relying on this cause of action as a remedy for the harm that revenge pornography can cause may turn out to be a risky approach.

\section{Copyright}

Copyright may be a powerful tool for victims of revenge pornography who have taken the images themselves. ${ }^{77}$ The Copyright Act 1968 (Cth) provides immediate protection to the author of a photograph. ${ }^{78}$ The author of a photograph is the person who took the photograph. ${ }^{79}$ This protection gives the author exclusive rights to reproduce, ${ }^{80}$ publish $^{81}$ and communicate the work. ${ }^{82}$ The protections for filming are substantially the same. ${ }^{83}$ Accordingly, a perpetrator infringes copyright when they distribute an image that they did not take. Website hosts may also infringe copyright by authorising infringing material on their website. ${ }^{84}$ Damages and account of profits are available for an infringement of copyright, as well as a final injunction preventing the infringer from engaging in further infringing conduct. ${ }^{85}$ However, remedies based on copyright law will not necessarily protect those victims who have been photographed or filmed by others. Furthermore, copyright laws may not provide remedies against websites that are hosted in other nations. Consequently, victims whose images are hosted on foreign websites must attempt to trace the hosts and request that the images be removed themselves.

76 Hancy, above n 69, 23.

77 Amanda Levendowski, 'Using Copyright to Combat Revenge Porn' (2014) 3 New York University Journal of Intellectual Property and Entertainment Law 422; Jessica Lake, “'Overexposed": Legal Responses to the Unauthorised Publication of Private Photos' (2016) 3 Australian Media, Technology and Communications Law Bulletin 8, 9.

78 Copyright Act 1968 (Cth) s 32 provides copyright protection to the original author of artistic work; $\mathrm{s} 10$ defines that an artistic work includes a photograph.

79 Ibid s 10

80 Ibid s 31(b)(i).

$81 \quad$ Ibid s 31(b)(ii).

82 Ibid s 31(b)(iii).

83 Ibid s 90 copyright subsists in a cinematographic film of which the maker; s 10 definition of a cinematographic film means the aggregate of the visual images embodied in an article or thing so as to be capable by the use of that article or thing of being shown as a moving picture. This would no doubt include a smart phone to record intimate images.

$84 \quad$ Ibid s 36(1).

85 Ibid s 115(2). 
It is possible to apply to a court to have the website blocked by the carriage service provider if the primary purpose of the website is to facilitate copyright infringement, ${ }^{86}$ but that does not assist in having the images removed. Proving a copyright infringement and assessing damages can be an extremely difficult and lengthy process. In the meantime, intimate images can be continuously circulated, increasing the harm to victims.

\section{Alternative APPROACHES}

\section{A Action for Serious Invasion of Privacy}

Revenge pornography can be a serious form of privacy invasion for victims. Civil causes of action for serious invasion of privacy exist in New Zealand, ${ }^{87}$ the United States ${ }^{88}$ and Canada. ${ }^{89}$ At present, a cause of action for serious invasion of privacy does not exist in Australian law. This is despite the possibility being left open in Australian Broadcasting Corporation v Lenah Game Meats Pty $L t d^{90}$ and Australia being signatory to the International Covenant on Civil and Political Rights ${ }^{91}$ that requires Australia to protect the privacy of its citizens. ${ }^{92}$ The existence of an action for serious invasion of privacy has been recognised in the first instance decisions of Grosse v Purvis ${ }^{93}$ and Doe v Australian Broadcasting Corporation. ${ }^{94}$ However, the Victorian Court of Appeal rejected a claim for invasion of privacy in Giller $v$ Procopets ${ }^{95}$ and a similar attempt to recognise a tort of invasion of privacy was

\footnotetext{
86 Ibid s $115 \mathrm{~A}$

87 Hosking v Runting [2005] 1 NZLR 1; C v Holland [2012] 3 NZLR 672.

88 Restatement of the Law, 2nd, Torts 1977 (US) ss 652B-652D.

89 Privacy Act 1996 RSBC c 373 (British Columbia); Privacy Act CCSM section P125 (Manitoba); Privacy Act 1978 RSS c P-24 (Saskatchewan); Privacy Act 1990 RSNL c P-22 (Newfoundland and Labrador).

90 (2001) 208 CLR 199, 248 [107], 250 [110], 258 [132] (Gummow and Hayne JJ, with whom Gaudron J agreed), 279 [191] (Kirby J).

91 International Covenant on Civil and Political Rights, opened for signature 16 December 1966, 999 UNTS 171 (entered into force 23 March 1976).

92 Ibid art 17(1).

93 [2003] QDC 151.

94 [2007] VCC 281

95 (2008) 24 VR 1.
} 
rejected in the UK House of Lords in Wainwright v Home Office ${ }^{96}$ in 2003. The Australian Law Reform Commission ('ALRC'), ${ }^{97}$ the New South Wales Law Reform Commission ${ }^{98}$ and the Victorian Law Reform Commission ${ }^{99}$ have all recommended the introduction of a statutory cause of action for invasion of privacy and made suggestions for the possible elements for this cause of action.

In 2014, the ALRC recommended that a plaintiff could prove an invasion of privacy in two different ways: by either physical intrusion or by misuse of private information. ${ }^{100}$ The invasion would be actionable where a person in the position of the plaintiff had a reasonable expectation of privacy. ${ }^{101}$ In determining whether there was an expectation of privacy, the nature of the private information and the purpose of the misuse would be two factors to take into account. ${ }^{102}$ The invasion would need to be both serious and either intentional or reckless, but it need not cause actual damage. ${ }^{103}$ The court would also have to be satisfied that the plaintiff's privacy interests outweigh the defendant's rights to freedom of expression and any broader public interest. ${ }^{104}$ No doubt this cause of action would capture the non-consensual sharing of a person's intimate image. In March 2016, the New South Wales Legislative Council Standing Committee on Law and Justice also recommended introducing this cause of action. ${ }^{105}$ The recommended model is substantially the same as that recommended by the ALRC. At the time of writing the New South Wales government is yet to respond to the recommendations.

There is strong support from Law Reform Commissions in Australia for the enactment of this cause of action. ${ }^{106}$ The most pressing argument in favour of

96 [2004] 2 AC 406.

97 Australian Law Reform Commission, Serious Invasion of Privacy in the Digital Era, Final Report (2014).

98 New South Wales Law Reform Commission, Invasion of Privacy, Report 120 (2009).

99 Victorian Law Reform Commission, Surveillance in Public Places, Report 18 (2010).

100 Australian Law Reform Commission, above n 97, 9.

101 Ibid.

102 Ibid.

103 Ibid.

104 Ibid.

105 Senate Legal and Constitutional Affairs References Committee, above n 3, 57.

106 Australian Law Reform Commission, For Your Information: Privacy Law and Practice, Report 108 (2008) 2557; New South Wales Law Reform Commission, Invasion of Privacy, 
this statutory cause of action is that existing legal protections are not adequate to deal with advances in technology and communication. ${ }^{107}$ This is true for victims of revenge pornography, who can be left without adequate redress. The action would provide courts with the power to make orders for damages for emotional distress, injunctions and destruction and removal of the intimate images. ${ }^{108}$ The action would also implement Australia's international obligation to provide people with an effective remedy for interference with privacy ${ }^{109}$ and protect the interest that each person has in maintaining personal privacy.

Arguments against introducing this cause of action are concerned with the impact such an action may have on the public interest in freedom of expression. ${ }^{110}$ There is no constitutional right to freedom of speech or expression in Australia, but a right does exist at common law. ${ }^{111}$ It has been argued that an action for serious invasion of privacy may have a 'chilling effect' on certain forms of artistic expression and freedom of the media. ${ }^{112}$ For example, under the proposed action, a person could seek an injunction from the court to prevent a media organisation publishing information about them. This could adversely affect the legitimate role of the media in creating public awareness in, and exposing the malpractices of, governments, corporations and individuals in power.

An intrusion into freedom of expression is, however, exactly the purpose of an action in invasion of privacy. As outlined above, the court would do this only where the privacy interests of a person demonstrably outweighed the countervailing interest in freedom of expression. Despite this, the Australian government has refused to embrace the enactment of an action for serious

above n 98, 8-10; Victorian Law Reform Commission, Surveillance in Public Places, above n $99,147$.

107 David Rolph, 'Towards an Australian Law of Privacy: The Arguments For and Against' (2012) 31(4) Communications Law Bulletin 9, 10.

108 Australian Law Reform Commission, above n 97, 12.

109 International Covenant on Civil and Political Rights, opened for signature 16 December 1966, 999 UNTS 171 (entered into force 23 March 1976) art 17(2).

110 Australian Law Reform Commission, above n 106, 2559; New South Wales Law Reform Commission, above n 98, 9-10.

111 Nationwide News v Wills (1992) 177 CLR 1, 32 (Mason CJ); Attorney-General (South Australia) v Corporation of the City of Adelaide (2013) 249 CLR 1, 67 [151]; Monis v The Queen (2013) 249 CLR 92, 128 [60].

112 Rolph, above n 107, 13. 
invasion of privacy. Furthermore, even if a statutory tort of invasion of privacy were to be enacted, it would require a victim of revenge pornography to bring an action in court. Given that the ordinary person does not possess the expertise and skill to file and defend a civil claim in court, victims will usually need to seek the advice and services of a lawyer. Lawyers are expensive and it can take years to obtain a court decision. Victims need fast removal of the images to reduce the harm that may potentially be inflicted on them; but the statutory action for serious invasion of privacy does not provide such a response.

\section{B The Australian Online Safety Response for Children}

A second approach to the problem of revenge pornography can be found in the Enhancing Online Safety for Children Act 2015 (Cth) ('the Online Safety Act'), which came into effect on 1 July 2015. ${ }^{113}$ The Online Safety Act was enacted in response to the prevalence of cyber-bullying among children and young people and the devastating long terms impacts this conduct can have on a child. ${ }^{114}$ The Online Safety Act creates a new independent statutory office, the Office of the Children's e-Safety Commissioner ('the Office'), ${ }^{115}$ to take a national leadership role in promoting online safety for children. ${ }^{116}$

The main function of the Office is to administer a complaints system to assist in the rapid removal of cyber-bullying material ${ }^{117}$ targeted at Australian children on both social media sites and other electronic services. ${ }^{118}$ Other electronic services are defined to include chat services, websites, emails and photo sharing services such as Instagram or SnapChat. ${ }^{119}$ Revenge pornography involving people under 18 is likely to constitute harmful material to an Australian child for which the Office can take action. The Office also has the power to investigate complaints about other illegal content hosted online,

113 Enhancing Online Safety for Children Act 2015 (Cth) s 2.

114 Department of Communications, Enhancing Online Safety for Children, Discussion Paper (2014) 4

115 Enhancing Online Safety for Children Act 2015 (Cth) s 14.

116 Ibid ss 15(1)(b)-(s).

117 Enhancing Online Safety for Children Act 2015 (Cth) s 5(1)(b) defines that material is cyberbulling material if an ordinary reasonable person would conclude, that it is likely that the material was intended, and is likely to have the effect of, seriously threatening, seriously intimidating, seriously harassing or seriously humiliating the Australian child.

118 Ibid s18; see also Department of Communications, Enhancing Online Safety for Children, Discussion Paper (2014) 9.

119 Enhancing Online Safety for Children Act 2015 (Cth) s 4 (definition of 'relevant electronic service'). 
including the sharing of sexual images of Australian children. ${ }^{120}$ The Office has powers to enforce civil penalties against both social media sites and against the person who posted the harmful content. ${ }^{121}$ An extension of the Online Safety Act to adult victims would be an efficient and effective way to enable adults to make complaints about revenge pornography and to aid in the speedy removal of the images from the internet.

The Online Safety Act does not apply to all social media services. The service must fall within one of two tiers before it can be subject to the powers of the Office. The Office declares a service as participating under 'tier 1' if they comply with the basic online safety requirements for social media services. ${ }^{122}$ These requirements include a provision in the terms of use that prohibits the posting of cyber-bullying material ${ }^{123}$ and a complaints scheme to enable a request for the removal of cyber-bullying material. ${ }^{124}$ On the other hand, 'tier 2' services lack effective and well-resourced complaints systems. Only the Minister for Communications ('the Minister') can make a declaration that a social media service is a 'tier 2' service. ${ }^{125}$ The Minister will do this only if the service is a large social media service and the Office has recommended it be categorised as a 'tier 2' service. ${ }^{126}$ When there is a complaint about cyberbullying material the complainant is first required to request the removal of the material from the social media website. ${ }^{127}$ The Office will proceed with a complaint if the complainant's request for the removal of the material has been ignored for 48 hours. ${ }^{128}$ Following an investigation, the Office may request the social media service remove the material. ${ }^{129}$ The advantage that a 'tier 1 ' service has over a 'tier 2' service is that there is no legal obligation to comply with a request to remove material and there is no penalty for failing to comply with a request. For 'tier 2' services, if the request is not complied with within 48 hours, the Office can impose a civil penalty of up to $\$ 17000$, an enforceable

\footnotetext{
120 Ibid s 15(1)(a)(ii).

121 Ibid ss $36,46-48$.

122 Ibid ss 23(1), 23(4).

123 Ibid s 21(1)(a).

124 Ibid s 21(1)(b).

125 Ibid s 30(1).

126 Ibid ss 30(2), 31.

127 Ibid ss 29(1), 35(1)

128 Ibid ss 18(4)-(5).

129 Ibid ss 29(1)-(2).
} 
undertaking, or an injunction to comply with the request. ${ }^{130}$ The two-tiered scheme encourages large scale social media sites to implement effective complaints systems and to work co-operatively with the Office under the 'tier 1 ' scheme. If a 'tier 1' service repeatedly fails to respond to removal notices, the Office can revoke the service's 'tier 1' status. ${ }^{131}$ As the Office is already equipped to deal with complaints about revenge pornography on social media sites, extending the Office's power to adult victims could provide a satisfactory and cost effective means of achieving the fast removal of revenge pornography images from those services. However, this is not a comprehensive response, because it does not capture small-scale social media sites or other websites that may host revenge pornography material.

The Online Safety Act also creates an end-user scheme, ${ }^{132}$ which gives the Office the power to issue end-user notices to a person who posts cyber-bullying material on social media sites or other electronic services, including websites. ${ }^{133}$ The notice may require the end-user to remove the material, refrain from posting cyber-bullying material and even apologise. ${ }^{134}$ If the recipient of the notice fails to respond, the Office may go to court to seek an injunction to have the material removed ${ }^{135}$ or refer matters to the police. ${ }^{136}$ If the power of the Office were to be extended to include adult victims, the Office would then be able to issue take down notices to those who have posted material targeted at adults and impose civil penalties on adult end-users who fail to adhere to take-down requests. This may act as a deterrent for these types of behaviours and demonstrate to victims that action can be taken to force a person to remove their intimate images.

The main benefit of this scheme is that once the Office proceeds with a complaint it takes control over the removal of the material. The victim is no longer required to communicate with the social media service, website or person who posted the cyber-bullying material. The Office does not require complainants to make statements to police or to obtain a court order before action can be taken. If take-down notices are not complied with, the Office will

\footnotetext{
130 Ibid ss $36,47,48$.

131 Ibid s 25 .

132 Ibid s 42

133 Ibid s 42(1)(a)-(d).

134 Ibid s 42(1)(e)-(g).

135 Ibid ss 43, 48.

136 Ibid s 92.
} 
take court action or refer matters to the police. Victims no longer feel alone because they have the support of the Office behind them. The scheme is very effective. The Office has reported that since its inception there has been 100 per cent participation for removal requests from social media services. ${ }^{137}$ An extension of the Office's powers to receive and deal with complaints from adults would provide revenge pornography victims with a way to ensure that their images are removed from the internet as quickly as possible. At the same time, taking this action does not preclude any criminal investigation, nor does it prevent the victim pursuing civil remedies. Extending the powers of the Office to adult victims would be a significant improvement for victims of revenge pornography. However, the specific focus on social media services and end users means that other online content website hosts cannot be penalised for ignoring requests to take down revenge pornography material, nor are they encouraged to offer effective complaint reporting systems.

\section{The New Zealand Response}

In contrast to the Australian Online Safety Act, the New Zealand Harmful Digital Communications Act 2015 (NZ) ('Harmful Digital Communications $A c t^{\prime}$ ') provides assistance to both adult and child victims of harmful digital communications, which include revenge pornography. The purpose of the Harmful Digital Communications Act is to deter, prevent and mitigate harm caused to individuals by digital communication. ${ }^{138}$ Before the enactment of the Harmful Digital Communications Act, posting revenge pornography was not a criminal offence and people were required to seek removal of harmful material through lengthy and costly civil proceedings. The Harmful Digital Communications Act creates a hybrid scheme, providing both civil enforcement to deal quickly and efficiently with harmful digital communications, ${ }^{139}$ as well as criminal offences to deal with the most serious forms of conduct. ${ }^{140}$ The Harmful Digital Communication Act captures any form of electronic communication, including a text message, email, picture or recording. ${ }^{141}$ It also contains ten communication principles to guide online communication. ${ }^{142}$ For example, a digital communication should not be

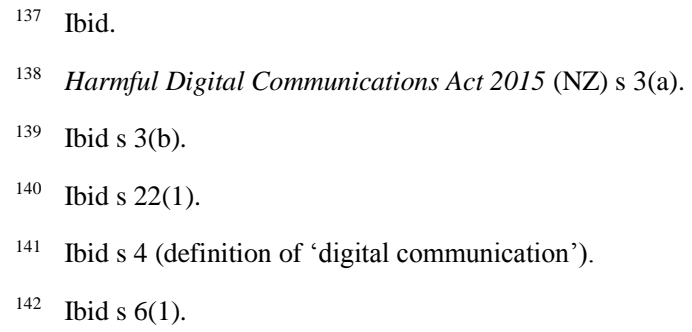


threatening, intimidating or menacing, ${ }^{143}$ indecent or obscene ${ }^{144}$ and should not be used to harass an individual. ${ }^{145}$ The Harmful Digital Communication Act protects both adults and children who allege that they have, or will, suffer harm as a result of a digital communication. ${ }^{146}$ The civil and criminal penalties created by the Act apply both to the person who posted the harmful material and to website hosts if they do not cooperate with the provisions for the removal of harmful material.

\section{Criminal Offence $e^{147}$}

The Harmful Digital Communication Act makes it a criminal offence to cause harm by posting a digital communication. ${ }^{148} \mathrm{~A}$ communication is posted, for example, when a person publishes by means of digital communication any intimate visual recording of another. ${ }^{149}$ Intimate visual recording includes photographs and videos of a person naked, semi naked, in their underwear or engaged in a sexual activity. ${ }^{150}$ The visual recording may have been made with or without the knowledge or consent of the person, but must have been made in a place where there was an expectation of privacy. ${ }^{151}$ To make out the offence: the offender must have posted the digital communication 'with the intention that it cause harm to a victim'; 'posting the communication would cause harm to an ordinary reasonable person in the position of the victim'; and, posting the communication does in fact cause harm to the victim. ${ }^{152}$ The harm required by the Harmful Digital Communications Act is serious emotional distress. ${ }^{153}$ In determining whether a post would cause serious emotional distress to an ordinary reasonable person the court may take into account such

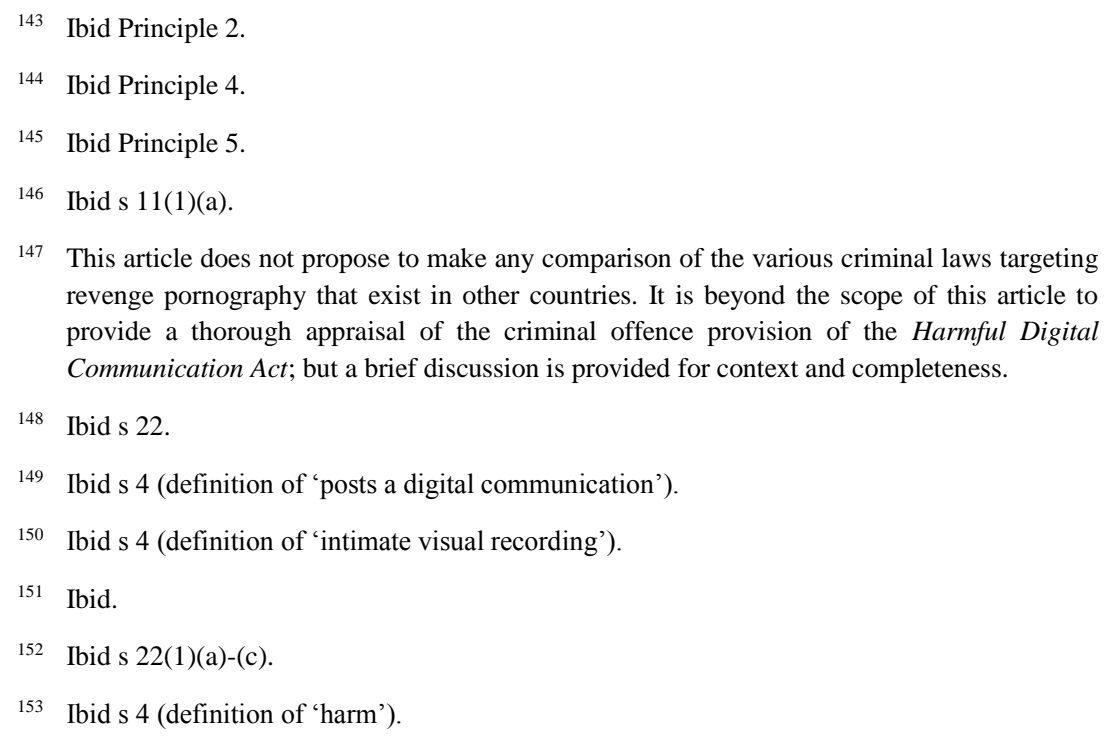


factors as the extent of circulation of the digital communication ${ }^{154}$ and the context in which it appeared. ${ }^{155}$ The offence is punishable by fine or up to two years imprisonment. ${ }^{156}$ Amber Hoskings ${ }^{157}$ identifies a number of criticisms of this offence. For example, the requirement that the person who posted the digital communication intend to cause harm to the victim could mean that intimate images posted for entertainment and notoriety would not be captured. ${ }^{158}$ Requiring the image to have been recorded where there has been an expectation of privacy, means that recordings in public may not be captured. ${ }^{159}$ Furthermore, even though the images do not need to be seen by others, it may be difficult to prove serious emotional stress where this has not occurred. ${ }^{160}$ The criminal offence established by the Harmful Digital Communications Act does not assist a victim with the speedy removal of the harmful digital communication. Rather, it is the civil enforcement regime that attempts to provide New Zealand victims with that response.

\section{Civil Enforcement Regime}

One of the major features of the Harmful Digital Communication Act is the establishment of an Approved Agency to deal with complaints about harmful digital communications that violate one or more of the ten communication principles. ${ }^{161}$ The Approved Agency is required to establish and maintain relationships with domestic and foreign service providers, online content hosts and other agencies to achieve the purposes of the Harmful Digital Communication Act. ${ }^{162}$ The Approved Agency assesses and investigates complaints and attempts to resolve them through the use of negotiation, mediation and persuasion. ${ }^{163}$ If the Approved Agency is unable to resolve the dispute, the complainant can apply to the District Court for a civil enforcement

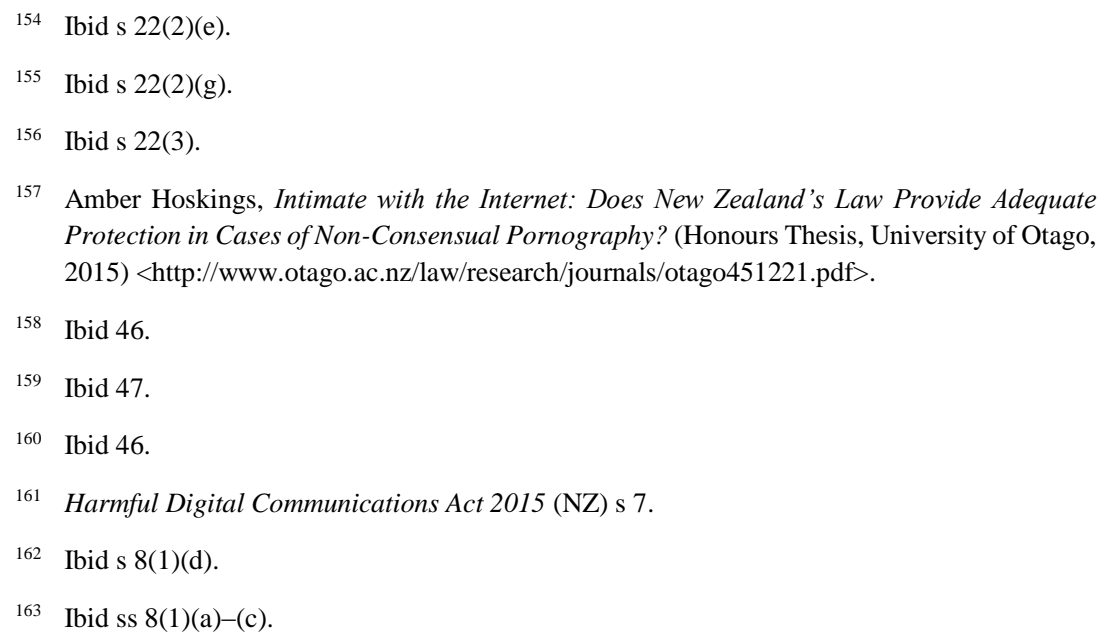


order. ${ }^{164}$ If the court is satisfied that there has been an actual or threatened serious breach of one of the ten communication principles, ${ }^{165}$ and the breach has caused, or is likely to cause, that person harm, ${ }^{166}$ the court can make an order against both the person who posted the material and the online content host. ${ }^{167}$ The court has the power to make an order requiring a person to remove the material in question, ${ }^{168}$ apologise, ${ }^{169}$ and restrain them from further breaches. ${ }^{170}$ The court may also make an order requiring the online content host to take down the harmful material, ${ }^{171}$ disclose the identity of the author ${ }^{172}$ and provide a correction ${ }^{173}$ or right of reply. ${ }^{174}$ Criminal penalties may be imposed on persons or online content hosts who do not comply with those orders. $^{175}$

One advantage of this scheme is that the Approved Agency is the first point of call for all complaints. Most complaints are likely to be dealt with by the Approved Agency, taking pressure off both law enforcement bodies and courts. ${ }^{176}$ Unlike the Office in Australia, however, the Approved Agency is not empowered to issue take-down notices and to impose civil penalties on those who do not comply with requests for the removal of harmful material. The complainant is left to seek that assistance from the court. This means that the Harmful Digital Communication Act is unlikely to provide the quick and efficient redress to victims that it promises. The cost of initiating proceedings is left to the victim, which denies access to justice for those who cannot afford it.

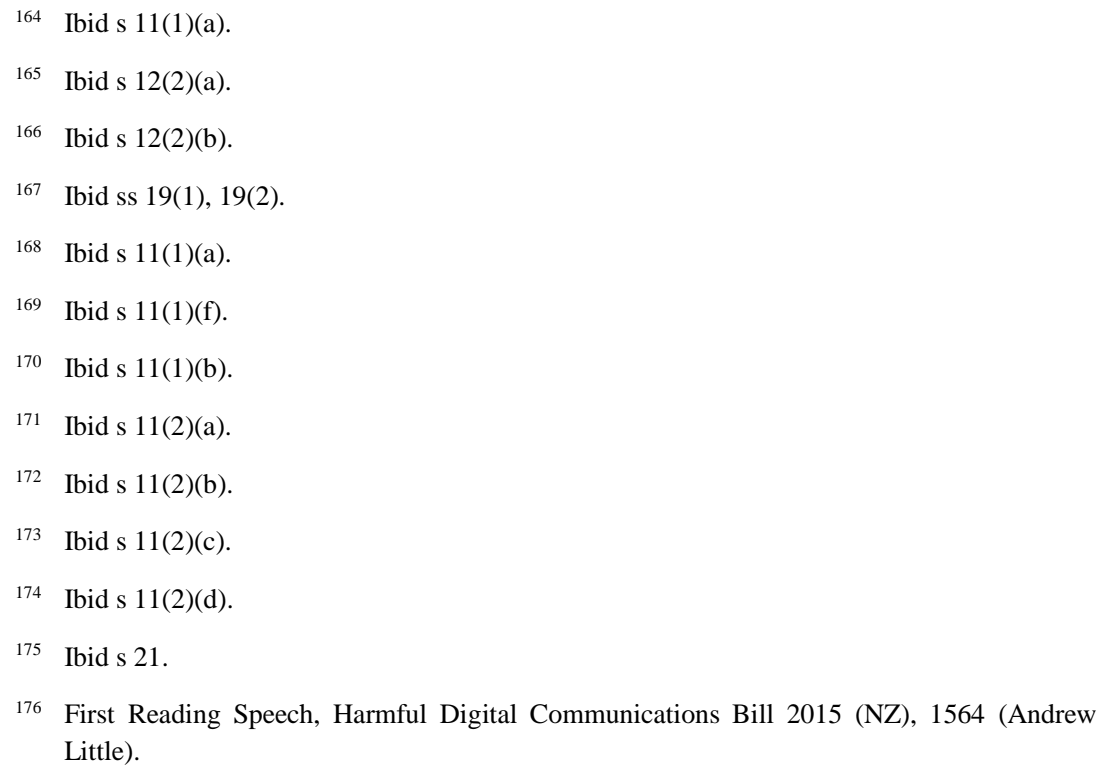
Little). 


\section{Safe Harbour Provisions}

The Harmful Digital Communication Act also provides an opt-in safe harbour provision to protect online content hosts from civil or criminal liability. ${ }^{177}$ To be afforded this protection, the host must provide an accessible way for people to contact them about harmful digital communications. ${ }^{178}$ Where the online content host receives a notice of complaint ${ }^{179}$ about harmful content, the host has 48 hours to provide a copy of the notice to the author. ${ }^{180}$ If the host is unable to contact the author they must take down the content within 48 hours. ${ }^{181}$ If the author can be contacted, the host is required to tell the author to provide a counter-notice ${ }^{182}$ within 48 hours of receiving the complaint either consenting, or refusing to consent, to the removal of the content. ${ }^{183}$ If the author consents, the content must be taken down as soon as possible. ${ }^{184}$ If the author does not consent, then the content can remain and the host must provide the complainant with personal information that identifies the author, ${ }^{185}$ unless of course it breaches one of the user terms and conditions. If the author does not reply, the host must wait the full 48 hours before content can be removed. ${ }^{186}$ The ease and speed with which content can be posted online means that the majority of content hosts do not see the content before it is posted. The safe harbour provisions recognise that online content hosts should not be responsible for content of which they have no knowledge. ${ }^{187}$

The Australian Online Safety Act provides a similar safe harbour for 'tier 1' social media services. However, because the civil penalties created by the Online Safety Act do not apply to online content hosts, there is no incentive to provide effective complaints systems and to keep their sites safe from harmful

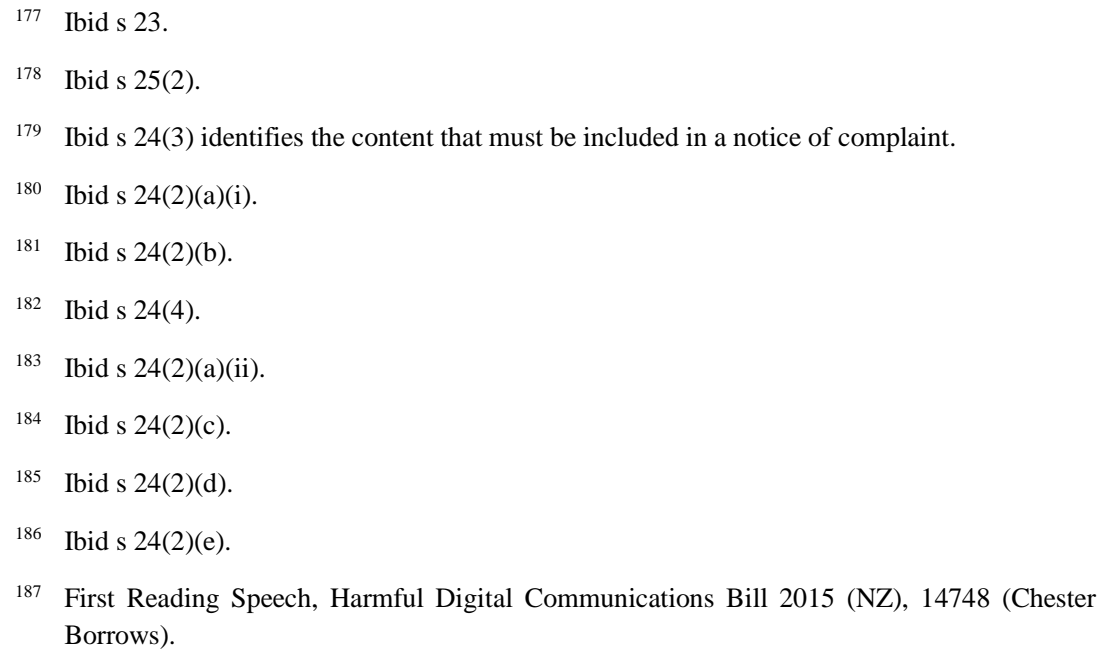


content. ${ }^{188}$ The Australian Parliament should consider implementing a scheme similar to the Harmful Digital Communications Act, whereby it provides a government body with specific powers to impose civil penalties on online content hosts and opt-in safe harbour provisions to protect those hosts who provide effective complaints systems and cooperate with the government body in the removal of harmful content. Enabling the victim to obtain the quick removal of revenge pornography directly from the online content host would be an efficient and effective measure and one that the Australian Parliament should consider.

\section{Appraisal}

One concern in establishing legislation that prohibits offensive and harmful online content is the impact that the legislation may have upon the freedom of expression and speech. In the parliamentary debates leading up to the enactment of the Harmful Digital Communication Act it was argued that the ten communication principles were too broad. One concern was that the broad principles in the Harmful Digital Communication Act could prevent the media from reporting stories of genuine public interest. ${ }^{189}$ For example, Principle 1 states that a digital communication should not disclose sensitive personal facts about an individual. ${ }^{190}$ This would mean that disclosing the dishonest dealings of a politician could be caught because it would likely cause the politician serious emotional distress. The concern about the impact on freedom of speech is amplified by the fact that the Harmful Digital Communication Act does not contain specific defences such as truth, satire, consent, political opinion or public interest, which are available under other existing laws.

The right to freedom of speech is not an absolute right and does not curtail the need to protect other rights. ${ }^{191}$ There needs to be a limit on the freedom of speech and expression to the extent necessary to avoid serious emotional harm. The Online Safety Act tries to balance this need by providing the narrowest definition of cyber-bullying possible that is consistent with its objectives; only conduct likely to cause serious harm to victims will be targeted. Furthermore, the Online Safety Act also allows an appeal against a take-down notice. ${ }^{192}$

188 Committee Debate, Harmful Digital Communications Bill 2015 (NZ), 4654 (David Parker).

189 Committee Debate, Harmful Digital Communications Bill 2015 (NZ), 4676 (Clare Curran).

190 Harmful Digital Communications Act 2015 (NZ) s 6.

191 Third Reading Speech, Harmful Digital Communications Bill 2015 (NZ), 4871 (Scott Simpson).

192 Enhancing Online Safety for Children Act 2015 (Cth) s 88. 
Consistently with the Online Safety Act, if the Australian Parliament were to implement a government body to deal with adult victims of revenge pornography, the conduct that they are empowered to deal with should be limited to conduct that is likely to cause serious harm to the victim. This would limit the chilling effect on freedom of speech in Australia and also prevent overloading the government body with frivolous investigations.

The advantages of the Harmful Digital Communication Act are: first, that it applies to both adult and child victims; and secondly, that the civil penalties created by the Act apply both to the person who posted the harmful material and to the online content hosts who do not cooperate with the complaint and take-down process. These are the aspects that the Australian Parliament should consider implementing. However, the power to enforce those civil penalties should remain with the government body and not the courts, as is the case with the powers of the Office created by the Online Safety Act.

\section{CONCLUSION}

Distributing intimate images of a person as an act of revenge is not a new phenomenon. It is the ease and speed with which these images can now be disseminated on the internet that has caused revenge pornography to become a global concern. As Martin CJ recently pointed out in Sims v Jooste [No 2$]^{193}$ '[f]or the first time in human history, a significant portion of the population of the planet - a group measured in billions ... can access material from a single source. ${ }^{194}$ Once intimate images are on the internet, victims lose control over who can view the image. To mitigate the harm that ongoing public access to the image can cause, victims need assistance to enable the removal of the image from the internet as quickly as possible.

This article has argued that existing criminal sanctions and traditional civil remedies are not an adequate response to revenge pornography. A coordinated effort to enact specific criminal sanctions across all Australian jurisdictions would help to equip law enforcement and prosecution agencies to secure convictions. However, even with specific revenge pornography offences, an adult victim cannot currently seek to enforce the removal of an image until after a conviction has occurred. Criminal laws play an important role in deterring others and providing victims with a sense of justice, but criminal laws alone are not sufficient to deal with the problem. Breach of confidence and

193 [2016] WASCA 83.

194 [2016] WASCA 83, 7 [15]. 
copyright laws can assist victims in the removal and destruction of the image, in stopping further distribution of the image and by providing monetary remedies to the victim. However, these remedies will be available only if the victim has access to the court system - and obtaining these remedies from the court can take a long time. Introducing a statutory action for serious invasion of privacy would not improve this situation because remedies for this action will need to be pursued by the victim in the same way. By the time the criminal or civil courts can enforce the removal of the image, it may have been viewed, downloaded, copied and recirculated hundreds or even thousands of times, amplifying the harm that distribution can cause. Victims need a response that focuses on reducing this harm and enabling the fast removal of the images from the internet.

When considering how best to respond to revenge pornography, the Australian Parliament should focus on ways to best reduce the harm that ongoing public access to the intimate images can cause to victims. New Zealand sought to give victims this support with the Harmful Digital Communication Act, which provides victims with an efficient means of removing harmful material like revenge pornography. In Australia, the same assistance has been provided to Australian children who are victims of cyber-bullying material by the Online Safety Act. Both Acts respond to victims' needs by establishing an independent government body to deal with complaints. The Australian Online Safety Act goes even further and gives the Office of the e-Safety Commissioner power to intervene and take control of the efforts to remove the prohibited material from the websites. These regimes put the needs of victims first because they are no longer required to pursue action on their own.

The Australian Parliament should provide a similar regime for Australian adults. Extending the powers of the Office to cyber-bullying material, including revenge pornography directed at an adult, would be a logical step. The Office is already equipped to deal with complaints about revenge pornography and to impose civil penalties. It has established relationships with social media services and other electronic service providers. Extending the powers of the Australian Office to adults, in addition to providing a similar civil penalty and safe harbour regime targeted at online content hosts that is afforded to New Zealand victims by the Harmful Digital Communication Act, would enable the fast removal of intimate images and assist in reducing the harm that ongoing public access to the images can cause. This response focuses on the needs of victims. It would assure revenge pornography victims that prompt action can be taken and that a sense of dignity and control can be restored. 